\title{
Intramolecular hydrogen bonding and tautomerism in Schiff bases: Part VI. Syntheses and structural investigation of salicylaldimine and naphthaldimine derivatives
}

\author{
SELEN BILGE ${ }^{1, *}$, ZEYNEL KILIÇC $^{1}$, ZELIHHA HAYVALI $^{1}$, TUNCER HÖKELEK $^{2}$ and \\ SERAP SAFRAN ${ }^{2}$ \\ ${ }^{1}$ Department of Chemistry, Faculty of Science, Ankara University, Tandoğan, Ankara 06100, Turkey \\ ${ }^{2}$ Department of Physics, Hacettepe University, Beytepe, Ankara 06800, Turkey \\ e-mail: sbilge $@$ science.ankara.edu.tr
}

MS received 19 September 2008; revised 4 June 2009; accepted 15 July 2009

\begin{abstract}
Salicyclaldimines (5-9) and naphthaldimines (10-13) derived from condensation reactions of $\mathrm{N}_{2} \mathrm{O}_{2}$ donor type bifunctional aminopodands (1-4), $\left[\left(\mathrm{H}_{2} \mathrm{NPhO}\right)_{2} \mathrm{R}\right.$, where $\mathrm{R}=\mathrm{CH}_{2} \mathrm{CH}_{2}, \mathrm{CH}_{2} \mathrm{CH}_{2} \mathrm{CH}_{2}$ and $\mathrm{CH}_{2} \mathrm{PhCH}_{2}$ ], and hydrazine monohydrate with salicylaldehyde and 2-hydroxy-1-naphthaldehyde, respectively, have been prepared (scheme 1) and characterized by elemental analyses, UV-vis, FTIR, NMR and MS. NMR assignments were made using ${ }^{1} \mathrm{H},{ }^{13} \mathrm{C}$ NMR, DEPT and aided by $2 \mathrm{D}$ HETCOR and HMBC heteronuclear correlation techniques. The UV-vis spectra of the Schiff bases have been systematically studied in organic solvents of different polarity, acidic and basic media and found useful in understanding of tautomeric equilibria (phenol-imine, $\mathrm{O}-\mathrm{H} . . . \mathrm{N}$ and keto-amine, $\mathrm{O} \ldots \mathrm{H}-\mathrm{N}$ forms) in this series. The molecular structure of $\mathbf{8}$ has been determined crystallographically, and observed that the compound is in the form of phenol-imine, defined by the strong intramolecular $[\mathrm{O}-\mathrm{H} . . . \mathrm{N}=1.72(3), 1.81(2) \AA]$ hydrogen bonds. Compound 8 crystallizes in the monoclinic space group $P 2_{1} / a$ with $a=8.4675(7), b=38.448(3)$, $c=9.3875(7) \AA, \beta=103.0780(10)^{\circ}, V=2976.9(4) \AA^{3}, Z=4$ and $D_{x}=1.271 \mathrm{Mg} \mathrm{m}^{-3}$, and contains acetonitrile molecule in the crystal lattice.
\end{abstract}

Keywords. 2-Hydroxy Schiff bases; hydrogen bonding and tautomerism; crystal structure; heteronuclear correlation techniques.

\section{Introduction}

2-Hydroxy Schiff bases formed by condensation reactions of salicylaldehyde and 2-hydroxy-1naphthaldehyde with various amines have been extensively studied. ${ }^{1-7}$ This originated from the fact that the 2-hydroxy Schiff bases and their metal complexes exhibit wide applications, especially in biological systems. ${ }^{8-13}$ The presence of ortho hydroxyl group in Schiff bases has been regarded as one of the important elements favouring for the existence of intramolecular hydrogen bonds and also the tautomerism accounting for the formation of either phenol-imine $(\mathrm{O}-\mathrm{H} \ldots \mathrm{N})$ or keto-amine $(\mathrm{O} \ldots \mathrm{H}-\mathrm{N})$ tautomers. Intramolecular hydrogen bonds and tautomerism between phenol-imine and keto-amine forms in 2-hydroxy Schiff bases in solution and in the solid state have been investigated by using IR

\footnotetext{
*For correspondence
}

and UV-vis, ${ }^{14-17}{ }^{1} \mathrm{H},{ }^{13} \mathrm{C}$ and ${ }^{15} \mathrm{~N}$ NMR spectroscopic $^{18,23}$ and $\mathrm{X}$-ray crystallographic ${ }^{24}$ techniques. The spectroscopic and crystallographic investigations into 2-hydroxy Schiff bases lies in the eminent importance of intramolecular hydrogen bonds for distinguishing their photochromic and thermochromic behaviours $^{25-32}$ as a consequence of intramolecular proton transfer between phenolic oxygen and imine nitrogen sites in the six-membered chelate ring formed. In solution, the existence of tautomeric equilibra in polar and non-polar solvents is observed. ${ }^{33} \mathrm{It}$ is claimed that phenol-imine form is dominant in salicylaldimine, while keto-amine form in naphthaldimine Schiff bases in solution. ${ }^{34,35}$ In the solid state, it is generally specified by $\mathrm{X}$-ray analysis that salicylaldimine and naphtaldimine Schiff bases also tend to form phenol-imine and keto-amine, respectively. ${ }^{24,36,37}$ It was once claimed that the hydrogen bond type depends neither on the stereochemistry of the molecule, nor on the sort of the substituent 


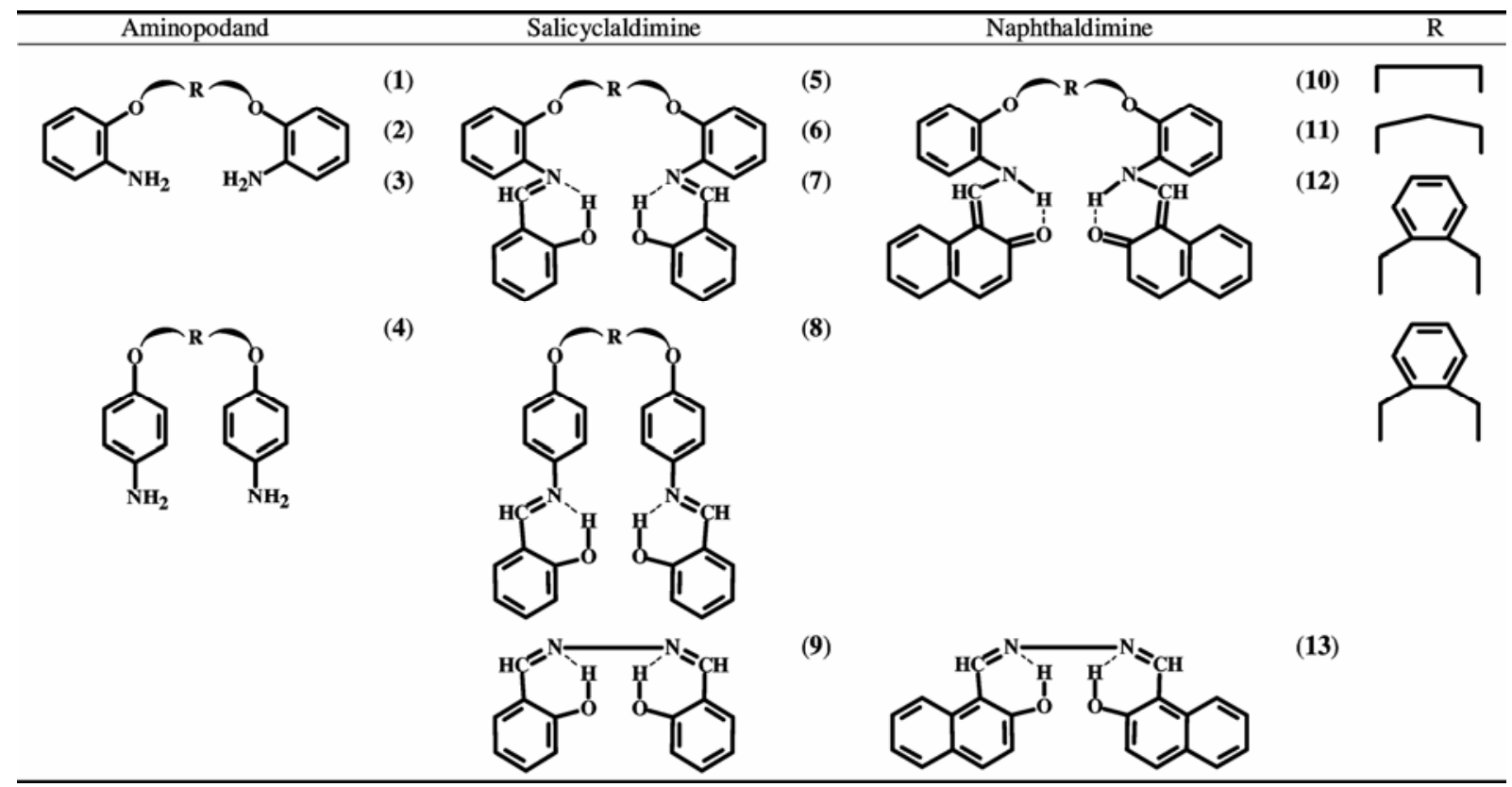

Scheme 1.

bonded to the imine nitrogen atom, but on the kind of aldehyde used, ${ }^{36}$ with only an intramolecular $\mathrm{O}-\mathrm{H}$...N (phenol-imine form) type of hydrogen bond being observed in salicyclaldimines, and an $\mathrm{O} \ldots \mathrm{H}-\mathrm{N}$ (keto-amine form) type in naphthaldimine. ${ }^{24,36,37}$ Our crystallographic studies have shown an intramolecular [O-H...N (phenol-imine tautomer)] hydrogen bond for 13, a naphthaldimine Schiff base, ${ }^{38}$ which is contrary to the observations reported in the literature. $^{24,37}$ On the other hand, 4-\{[(1E)-(2-hydroxynaphthyl)methylidene]amino -1,5-dimethyl-2-phenyl2,3-dihydro-1H-pyrazol-3-one ${ }^{39}$ and bis(2-hydroxy1-naphthaldehyde) oxaloyldihydrazone dihydrate ${ }^{40}$ also indicate that the naphthaldimine can exist in the phenol-imine form. In addition, according to our crystallographic data 4-\{[(1E)-(3,5-dinitro-2-hydroxyphenyl)-methylidene amino \}-1,5-dimethyl-2-phenyl2,3-dihydro- $1 H$-pyrazol-3-one, a salicylaldimine derivative, has neither phenol-imine nor keto-amine form, ${ }^{41}$ which is also contrary to the observations reported in the literature. ${ }^{24,36}$ The molecular structure observed in this compound corresponds to the situation where symmetric hydrogen bonds exist between the two forms, which might be artifact due to the disorder caused by proton transfer. Consequently, these results are clear evidences for the stereochemistry of the compounds and the $\mathrm{N}$-substituents in 2hydroxy Schiff bases. Therefore, there has been much interest in our laboratory on the subject of hydrogen bonds in salicylaldimine and naphthaldimine Schiff bases with different substituents.
In this paper, we report (i) the synthesis of 2hydroxy Schiff bases $(7,8$ and 12) where there are intrinsic aromaticity differences resulting from the condensation of salicylaldehyde and 2-hydroxy-1naphthaldehyde with $\mathrm{N}_{2} \mathrm{O}_{2}$-donor type bifunctional aminopodands (3 and 4) (scheme 1) and (ii) tautomerism via hydrogen bonding. The tautomeric conformers in crystal and liquid phases are investigated by spectroscopic methods and X-ray diffraction techniques. In addition, total assignments of ${ }^{1} \mathrm{H}$ and ${ }^{13} \mathrm{C}$ NMR spectra for the structures are made with the help of C-H correlation spectroscopy (HETCOR), as well as heteronuclear multiple-bond correlation (HMBC).

\section{Experimental}

\subsection{General techniques}

Salicylaldehyde and 2-hydroxy-1-naphthaldehyde were purchased from Fluka and used without further purification. $\mathrm{MeOH}, \mathrm{EtOH}, \mathrm{DMSO}, \mathrm{CH}_{2} \mathrm{Cl}_{2}$ and $n$ hexane were dried by standard methods prior to use. Melting points were measured on a Gallenkamp apparatus using a capillary tube. ${ }^{1} \mathrm{H},{ }^{13} \mathrm{C}$ NMR, DEPT, HETCOR and HMBC spectra were obtained on a Bruker $500 \mathrm{MHz}$ ultrashield spectrometer equipped with a $5 \mathrm{~mm}$ PABBO BB-inverse gradient probe. Standard Bruker pulse programs ${ }^{42}$ were used in the entire experiment. FTIR spectra were recorded on a Mattson 1000 FTIR spectrometer in $\mathrm{KBr}$ discs and 
were reported in $\mathrm{cm}^{-1}$ units. Microanalyses were carried out by the microanalytical service of TÜBITTAK (Turkey), Mass Spectrometric analysis (APIMS) were performed on the AGILEND 1100 MSD spectrometer. UV-vis spectra were measured by using a UNICAM UV2-100 series spectrometer.

\subsection{Synthesis of Schiff bases}

$\mathrm{N}_{2} \mathrm{O}_{2}$ donor type bifunctional aminopodands 1,2ethane dioxy bis(2-aminophenyl ether) (1), 1,3propane dioxy bis(2-aminophenyl ether) (2), 1,2xylylene dioxy bis(2-aminophenyl ether) (3) and 1,2-xylylene dioxy bis(4-aminophenyl ether) (4) have been synthesized from the reduction of the corresponding nitropodands with $\mathrm{Pd} / \mathrm{C}$ and hydrazine hydrate $(80 \%)$ in EtOH. ${ }^{15,43}$ The salicyclaldimine (5-9) and naphthaldimine (10-13) Schiff bases have respectively been obtained from the reaction of corresponding aminopodands (1-4) and hydrazine monohydrate in $\mathrm{MeOH}$ (scheme 1). The preparation and crystallographic data of 1,3-bis[N-2-oxyphenylsalicylidene]-propane (6) and 2-hydroxynapthaldehyde[(1E)-(2-hydroxynaphthyl)methylene]hydrazone (13) were reported by our group, previously, ${ }^{38,44}$ but the MS, IR, NMR and UV data of these compounds will be discussed in this paper. The syntheses of 1,2-bis[ $\mathrm{N}$-2-oxyphenyl-salicylidene]-ethane $\quad$ (5), ${ }^{45}$ 2-hydroxysalicylaldehyde[(1E)-(2-hydroxysalicyl) methylene]hydrazone (9), ${ }^{46}$ 1,2-bis[N-2-oxyphenyl2-oxo-1-naphthylidenemethylamino]-ethane $\mathbf{( 1 0})^{47}$ and 1,3-bis[N-2-oxyphenyl-2-oxo-1-naphthylidenemethylamino]-propane $(\mathbf{1 1})^{48}$ have also been reported, previously. However, for compounds $\mathbf{5}$ and 10, suitable spectral data are not available ${ }^{45,47}$ and for compound 9 only the crystallographic results are present. ${ }^{46}$ For the assignments of aromatic protons and carbons, we re-synthesized 5, 6, 9-11 and 13 and obtained the detailed NMR spectra of all the compounds for comparision purposes. Elemental analyses, FTIR, APIMS and all the NMR data are in agreement with the proposed structures of 7, 8 and 12. The MS spectra of the compounds (5-13) show protonated molecular ion $[\mathrm{MH}]^{+}$peaks. APIMS $\left(I_{\mathrm{r}} \%\right): m / z 453\left([\mathrm{MH}]^{+}, 100\right)$ for 5, $467\left([\mathrm{MH}]^{+}\right.$, 100) for 6, $241\left([\mathrm{MH}]^{+}, 8\right)$ for 9, $553\left([\mathrm{MH}]^{+}, 45\right)$ for 10, $567\left([\mathrm{MH}]^{+}, 63\right)$ for 11 and $341\left([\mathrm{MH}]^{+}, 100\right)$ for 13. IR $\left(\mathrm{KBr}, \mathrm{cm}^{-1}\right)$ : v $3061(\mathrm{C}-\mathrm{H}$ arom. $), 1617$ $(\mathrm{C}=\mathrm{N}), 1585(\mathrm{C}=\mathrm{C}), 1286 ; 1253(\mathrm{C}-\mathrm{O}$ arom. $), 1149$ 1035 (C-O aliph.) for 5, v 3060 (C-H arom.), 1616 $(\mathrm{C}=\mathrm{N}), 1589 \quad(\mathrm{C}=\mathrm{C}), \quad 1282 ; 1247 \quad(\mathrm{C}-\mathrm{O}$ arom. $)$,
1149-1040 (C-O aliph.) for 6, 3043 (C-H arom.), $1627(\mathrm{C}=\mathrm{N}), 1573(\mathrm{C}=\mathrm{C}), 1260(\mathrm{C}-\mathrm{O}$ arom. $)$ for $9, v$ $3067(\mathrm{C}-\mathrm{H}$ arom.), $1623(\mathrm{C}=\mathrm{N}), 1589(\mathrm{C}=\mathrm{C}), 1290$; 1257 (C-O arom.), 1163-1034 (C-O aliph.), 1323 $(\mathrm{C}=\mathrm{O})$ for $10, v 3055(\mathrm{C}-\mathrm{H}$ arom. $), 1623(\mathrm{C}=\mathrm{N})$, 1591 (C=C), 1290;1253 (C-O arom.), 1157-1047 $(\mathrm{C}-\mathrm{O}$ aliph.), $1321(\mathrm{C}=\mathrm{O})$ for 11 and $v 3063(\mathrm{C}-\mathrm{H}$ arom.), $1622(\mathrm{C}=\mathrm{N}), 1579(\mathrm{C}=\mathrm{C}), 1281(\mathrm{C}-\mathrm{O}$ arom. $)$ for 13 .

2.2a Synthesis of 1,4-bis[N-2-oxyphenyl-salicylidene ]-1,2-xylylene (7): A solution of $3(0.80 \mathrm{~g}$, $2.50 \mathrm{mmol})$ in dry $\mathrm{MeOH}(25 \mathrm{~mL})$ was added dropwise to a solution of salicylaldehyde $(0.61 \mathrm{~g}$, $5.00 \mathrm{mmol})$ in dry $\mathrm{MeOH}(50 \mathrm{~mL})$ over the period of $1 \mathrm{~h}$. The mixture was refluxed for $4 \mathrm{~h}$ and then cooled to an ambient temperature. After filtration, compound 5 was obtained as a yellow solid. It was recrystallized from $\mathrm{EtOH}$, m.p. $142^{\circ} \mathrm{C}, 1.04 \mathrm{~g}(79 \%)$ yield. Anal. calc. for $\mathrm{C}_{34} \mathrm{H}_{28} \mathrm{~N}_{2} \mathrm{O}_{4}$ : C 77.43, H 5.30, $\mathrm{N} 5 \cdot 26$; found: $\mathrm{C} 78 \cdot 10, \mathrm{H} 5 \cdot 25, \mathrm{~N} 5 \cdot 26$. APIMS $\left(I_{\mathrm{r}} \%\right): \mathrm{m} / z 529\left([\mathrm{MH}]^{+}, 100\right)$. IR $\left(\mathrm{KBr}, \mathrm{cm}^{-1}\right): v$ $3067(\mathrm{C}-\mathrm{H}$ arom.), $1616(\mathrm{C}=\mathrm{N}), 1586(\mathrm{C}=\mathrm{C}), 1283$; 1236 (C-O arom.), 1150-1030 (C-O aliph.).

\section{2b Synthesis of 1,4-bis[N-4-oxyphenyl-salicyli-} dene]-1,2-xylylene (8): Salicylaldehyde $(0.23 \mathrm{~g}$, $1.88 \mathrm{mmol})$ and $4(0.30 \mathrm{~g}, 0.94 \mathrm{mmol})$ were used for the preparation of 8 as for $7,3 \mathrm{~h}$, yellow solid, crystallization from $\mathrm{CH}_{3} \mathrm{CN}$, m.p. $149^{\circ} \mathrm{C}, 0.40 \mathrm{~g}(81 \%)$ yield. Anal. calc. for $\mathrm{C}_{34} \mathrm{H}_{28} \mathrm{~N}_{2} \mathrm{O}_{4}$ : C 77.43, H 5.30, $\mathrm{N} 5.26$; found: $\mathrm{C} 77.48, \mathrm{H} 5 \cdot 30, \mathrm{~N} 5 \cdot 30$. APIMS $\left(I_{\mathrm{r}} \%\right): \mathrm{m} / z 529\left([\mathrm{MH}]^{+}, 100\right)$. IR $\left(\mathrm{KBr}, \mathrm{cm}^{-1}\right): v$ $3061(\mathrm{C}-\mathrm{H}$ arom. $), 1616(\mathrm{C}=\mathrm{N}), 1590(\mathrm{C}=\mathrm{C}), 1286$; 1244 (C-O arom.), 1153-1037 (C-O aliph.).

\section{2c Synthesis of 1,4-bis [N-2-oxyphenyl-2-oxo-1-} naphthylidenemethylamino]-1,2-xylylene (12): A solution of $3(0.60 \mathrm{~g}, 1.88 \mathrm{mmol})$ in dry $\mathrm{MeOH}$ $(25 \mathrm{~mL})$ was added dropwise to a solution of 2hydroxy-1-naphthaldehyde $(0.65 \mathrm{~g}, 3.75 \mathrm{mmol})$ in dry $\mathrm{MeOH}(50 \mathrm{~mL})$ over the period of $1 \mathrm{~h}$. The mixture was refluxed for $4 \mathrm{~h}$ and then cooled to an ambient temperature. The precipitated yellow solid of 12 was filtered off and crystallized from $\mathrm{EtOH}$, m.p. $218^{\circ} \mathrm{C}, \quad 0.86 \mathrm{~g}(73 \%)$ yield. Anal. calc. for $\mathrm{C}_{42} \mathrm{H}_{32} \mathrm{~N}_{2} \mathrm{O}_{4}$ : C $80.24, \mathrm{H} 5 \cdot 13, \mathrm{~N} 4.46$; found: $\mathrm{C}$ 79.82, H 5.15, N 4.50. APIMS ( $\left.I_{\mathrm{r}} \%\right): m / z 629$ $\left([\mathrm{MH}]^{+}, 60\right)$. IR $\left(\mathrm{KBr}, \mathrm{cm}^{-1}\right): v 3058(\mathrm{C}-\mathrm{H}$ arom. $)$, $1620(\mathrm{C}=\mathrm{N}), 1591(\mathrm{C}=\mathrm{C}), 1290 ; 1248(\mathrm{C}-\mathrm{O}$ arom. $)$, 1161-1053 (C-O aliph.), $1323(\mathrm{C}=\mathrm{O})$. 
Table 1. Crystal data and structure refinement for $\mathbf{8}$.

\begin{tabular}{|c|c|}
\hline CCDC No. & 653274 \\
\hline Empirical formula & $\mathrm{C}_{34} \mathrm{H}_{28} \mathrm{~N}_{2} \mathrm{O}_{4} \cdot \mathrm{C}_{2} \mathrm{H}_{3} \mathrm{~N}$ \\
\hline Formula weight & 569.64 \\
\hline Temperature (K) & $273(2)$ \\
\hline Wavelength $(\AA)$ & 0.71073 \\
\hline Crystal System & Monoclinic \\
\hline Space Group & $P 2_{1} / a$ \\
\hline \multicolumn{2}{|l|}{ Unit cell dimensions } \\
\hline$a(\AA)$ & $8 \cdot 4675(7)$ \\
\hline$b(\AA)$ & $38 \cdot 448(3)$ \\
\hline$c(\AA)$ & $9 \cdot 3875(7)$ \\
\hline$\beta\left({ }^{\circ}\right)$ & $103 \cdot 0780(10)$ \\
\hline Volume $\left(\AA^{3}\right)$ & $2976 \cdot 9(4)$ \\
\hline$Z$ & 4 \\
\hline Density (calculated, $\mathrm{mg} / \mathrm{m}^{3}$ ) & $1 \cdot 271$ \\
\hline Absorption coefficient $\left(\mathrm{mm}^{-1}\right)$ & $0 \cdot 084$ \\
\hline$F(000)$ & 1200 \\
\hline Crystal shape and color & Plate, colorless \\
\hline Crystal size $\left(\mathrm{mm}^{3}\right)$ & $0.35 \times 0.25 \times 0.10$ \\
\hline Device type & Bruker 1000 CCD area-dedector diffractometer \\
\hline Scan type & $\varphi$ and $\omega$ scans \\
\hline Intensity decay $\%$ & 1 \\
\hline Counting time (min) & 120 \\
\hline$\theta$ range for data collection $\left(^{\circ}\right)$ & $2 \cdot 12-28 \cdot 27$ \\
\hline \multirow[t]{3}{*}{ Index ranges } & $-11 \leq h \leq 11$ \\
\hline & $-49 \leq k \leq 51$ \\
\hline & $-12 \leq l \leq 12$ \\
\hline Reflections collected & 31660 \\
\hline Independent reflections & $7186\left(R_{\text {int }}=0.0238\right)$ \\
\hline Observed reflections & $4930(I>2 \sigma I)$ \\
\hline Data/restraints/parameters & $7186 / 0 / 405$ \\
\hline Goodness-of-fit on $F 2$ & $1 \cdot 048$ \\
\hline Final $R$ indices $[I>2 \sigma(I)]$ & $R_{1}=0.0539, w R_{2}=0.1294$ \\
\hline$R$ indices (all data) & $R_{1}=0.0815, w R_{2}=0.1461$ \\
\hline Largest diff. peak and hole $\left(\mathrm{eA}^{-3}\right)$ & $0 \cdot 216$ and -0.281 \\
\hline Extinction coefficient & None \\
\hline
\end{tabular}

$w=1 /\left[\sigma^{2}\left(F_{\mathrm{o}}{ }^{2}\right)+(0.0576 P)^{2}+0.7621 P\right]$, where $P=\left(F_{\mathrm{o}}{ }^{2}+2 F_{\mathrm{c}}{ }^{2}\right) / 3$

Table 2. Selected bond lengths $(\AA)$, bond angles $\left({ }^{\circ}\right)$ and torsion angles $\left(^{\circ}\right)$ for 8 .

\begin{tabular}{llll}
\hline $\mathrm{O} 1-\mathrm{C} 1$ & $1 \cdot 345(3)$ & $\mathrm{O} 4-\mathrm{C} 30$ & $1 \cdot 350(2)$ \\
$\mathrm{O} 2-\mathrm{C} 11$ & $1 \cdot 3660(19)$ & $\mathrm{O} 3-\mathrm{C} 22$ & $1 \cdot 365(2)$ \\
$\mathrm{O} 2-\mathrm{C} 14$ & $1 \cdot 4441(19)$ & $\mathrm{O} 3-\mathrm{C} 21$ & $1 \cdot 412(2)$ \\
$\mathrm{N} 1-\mathrm{C} 7$ & $1 \cdot 278(2)$ & $\mathrm{N} 2-\mathrm{C} 28$ & $1 \cdot 272(2)$ \\
$\mathrm{N} 1-\mathrm{C} 8$ & $1 \cdot 414(2)$ & $\mathrm{N} 2-\mathrm{C} 25$ & $1 \cdot 416(2)$ \\
$\mathrm{C} 1-\mathrm{C} 6$ & $1 \cdot 399(3)$ & $\mathrm{C} 29-\mathrm{C} 30$ & $1 \cdot 404(2)$ \\
$\mathrm{C} 6-\mathrm{C} 7$ & $1 \cdot 448(3)$ & $\mathrm{C} 28-\mathrm{C} 29$ & $1 \cdot 448(3)$ \\
$\mathrm{N} 3-\mathrm{C} 35$ & $1 \cdot 115(4)$ & $\mathrm{C} 35-\mathrm{C} 36$ & $1 \cdot 437(4)$ \\
$\mathrm{C} 11-\mathrm{O} 2-\mathrm{C} 14$ & $118 \cdot 24(12)$ & $\mathrm{C} 22-\mathrm{O} 3-\mathrm{C} 21$ & $118 \cdot 75(14)$ \\
$\mathrm{C} 7-\mathrm{N} 1-\mathrm{C} 8$ & $122 \cdot 06(16)$ & $\mathrm{C} 28-\mathrm{N} 2-\mathrm{C} 25$ & $122 \cdot 52(15)$ \\
$\mathrm{O} 1-\mathrm{C} 1-\mathrm{C} 6$ & $121 \cdot 07(18)$ & $\mathrm{O} 4-\mathrm{C} 30-\mathrm{C} 29$ & $121.72(17)$ \\
$\mathrm{C} 1-\mathrm{C} 6-\mathrm{C} 7$ & $121 \cdot 95(18)$ & $\mathrm{C} 30-\mathrm{C} 29-\mathrm{C} 28$ & $121 \cdot 30(17)$ \\
$\mathrm{N} 1-\mathrm{C} 7-\mathrm{C} 6$ & $121 \cdot 62(18)$ & $\mathrm{N} 2-\mathrm{C} 28-\mathrm{C} 29$ & $121.90(17)$ \\
$\mathrm{N} 3-\mathrm{C} 35-\mathrm{C} 36$ & $179 \cdot 8(4)$ & & \\
$\mathrm{C} 8-\mathrm{N} 1-\mathrm{C} 7-\mathrm{C} 6$ & $-175 \cdot 45(15)$ & $\mathrm{C} 25-\mathrm{N} 2-\mathrm{C} 28-\mathrm{C} 29$ & $-179 \cdot 12(16)$ \\
$\mathrm{C} 1-\mathrm{C} 6-\mathrm{C} 7-\mathrm{N} 1$ & $0 \cdot 9(3)$ & $\mathrm{C} 30-\mathrm{C} 29-\mathrm{C} 28-\mathrm{N} 2$ & $-0.5(3)$ \\
$\mathrm{C} 7-\mathrm{C} 6-\mathrm{C} 1-\mathrm{O} 1$ & $-2 \cdot 4(3)$ & $\mathrm{C} 28-\mathrm{C} 29-\mathrm{C} 30-\mathrm{O} 4$ & $-1.7(3)$ \\
\hline
\end{tabular}




\section{$2.3 X$ X-Ray crystallography}

The suitable crystals of compound (8) were obtained by recrystallization from $\mathrm{CH}_{3} \mathrm{CN}$. The X-ray diffraction data have been collected on a Bruker 1000 CCD area-dedector diffractometer with $\mathrm{MoK}_{\alpha}$ radiation ( $\lambda=0.71073 \AA)$ at $273(2) \mathrm{K}$ and no absorption correction was applied due to the low absorption coefficient. The structure was solved by direct methods SHELXS97. ${ }^{49}$ Crystal data and structure refinement parameters are listed in table 1 and the crystallographic information file (CIF) is provided in the supplementary information. Selected bond lenghts $(\AA)$, bond angles $\left(^{\circ}\right)$ and torsion angles $\left(^{\circ}\right)$ are presented in table 2. H1A, H4A, H7 and $\mathrm{H} 28$ atoms were located from difference syntheses and refined isotropically. Since the difference syntheses did not clarify the positions of the remaining $\mathrm{H}$ atoms, they were positioned geometrically, with $\mathrm{C}-\mathrm{H}=0.93$, 0.97 and $0.96 \AA$ for aromatic, methylene and methyl $\mathrm{H}$, respectively and constrained to ride on their parent atoms with $U_{\text {iso }}(\mathrm{H})=x U_{\text {eq }}(\mathrm{C})$, where $x=1.5$ for methyl $\mathrm{H}$ and $x=1.2$ for all other $\mathrm{H}$ atoms.

\section{Results and discussion}

\section{$3.1 \quad$ FTIR spectroscopy}

The relevant IR spectral bands that can provide diagnostic structural evidences for 2-hydroxy Schiff bases are given in Experimental Section. For salicyaldimines (5-9) and naphthaldimine (13), relatively strong bands attributable to $v_{\mathrm{C}=\mathrm{N}}$ are detected at $1616-1627 \mathrm{~cm}^{-1}$ as in the Schiff bases possessing the formulation of $\mathrm{ArCH}=\mathrm{NAr}$ with substituted aryl groups which is assigned to $v_{\mathrm{C}=\mathrm{N}}$ involved in intramolecular hydrogen bond with the ortho $\mathrm{OH}$ group. ${ }^{17,36,50}$ The existence of intramolecular hydrogen bonds between the hydroxyl oxygens and the nitrogen atoms is further corroborated by X-ray structural data for $\mathbf{8}$. The observation of very weak $v_{\mathrm{C}=\mathrm{O}}$ absorption bands at 1323,1321 and $1323 \mathrm{~cm}^{-1}$ for naphthaldimines (10-12), respectively, is the evidence for the existence of the keto-amine tautomer in the solid state. Contrary to the expectation, analogue 13 does not show a similar absorption band at $\sim 1320 \mathrm{~cm}^{-1}$. Because, it is in the form of phenol-imine. Moreover, X-ray crystallographic data of 13 also support that there are two strong intramolecular $\mathrm{O}-\mathrm{H}$... N hydrogen bonds showing phenol-imine tautomer. ${ }^{38}$

\subsection{NMR spectroscopy}

The ${ }^{1} \mathrm{H}$ and ${ }^{13} \mathrm{C}$ NMR data of the compounds are listed in tables S1, S2 and S3 in Supplementary materials. The expected tautomeric species of salicylaldimine (5-9) and naphthaldimine (10-13) Schiff bases in solution are depicted in schemes 2 and 3. In addition, in solution the tautomeric species of the 2hydroxy Schiff bases determined by ${ }^{1} \mathrm{H}$ NMR spectroscopy are outlined in table 3 . In $\mathrm{CDCl}_{3}$, the ${ }^{1} \mathrm{H}$ NMR data for salicylaldimine derivatives (5-8) show the existence of only phenol-imine tautomer (scheme 2 (A)), while both keto-amine and phenolimine forms have been observed for naphthaldimine derivatives (10-12) (scheme 2 (A) and (F), figure 1, table S2). It means that the ${ }^{1} \mathrm{H}$ NMR spectra of naphthaldimine derivatives (10-12) show that both phenol-imine and keto-amine forms are in equilibria. The relative ratios of keto-amine/phenol-imine tautomers are estimated from the spectra of 10, 11 and 12 as $50 / 50,83 / 17$ and $95 / 5$, respectively. In DMSO, phenol-imine tautomer is only observed for salicylaldimines (5-8), while keto-amine tautomer for naphthaldimines (10-12). For instance, the doublets observed at $\sim 9.19$ and $\sim 15.80 \mathrm{ppm}$ (table S2), respectively, for the protons of $\underline{\mathrm{HC}}-\mathrm{NH}$ and $\mathrm{HC}-\mathrm{N} \underline{\mathrm{H}}$ of naphthaldimines (10-12) illustrate the keto-amine form as supported by the location of the hydrogen atom on nitrogen and leading to an $\mathrm{N}-\mathrm{H}$...O hydrogen bonding. Whereas, for salicylaldimines (5-8), two signals each appeared as a singlet at $\sim 8.76$ and $\sim 13.79 \mathrm{ppm}$ (table $\mathrm{S} 1$ ) can be ascribed to $\underline{\mathrm{HC}}=\mathrm{N}$ and $\mathrm{ArOH}$ indicated that the tautomeric equilibrium in these compounds favours the phenol-imine form in both $\mathrm{CDCl}_{3}$ and DMSO, showing $\mathrm{N}$...H-O hydrogen bonding and $E / E$ geometric isomer (scheme $2(\mathrm{~A})$ ). According to ${ }^{1} \mathrm{H}$ NMR spectra of compound 9, two geometric isomers (one of them is $E / E(\mathrm{~A})$, the other one is likely to be $E / E$ (B) or $Z / E$ (C), scheme 3) have been observed in $\mathrm{CDCl}_{3}$ (figure 1). In compound 13, a naphthaldimine derivative, only one of the geometric isomers of the phenol-imine form (possibly E/E (A) (scheme 3)) has been defined.

In the ${ }^{1} \mathrm{H}$ NMR spectra of salicyclaldimine (6) and naphthaldimine (11) Schiff bases in DMSO, the peaks at $7.59(d, 2 \mathrm{H}) ; 7.40(t, 2 \mathrm{H}) ; 6.95(t, 2 \mathrm{H}) ; 6.96$ $(d, 2 \mathrm{H}) ; 7.15(d, 2 \mathrm{H}) ; 7.02(t, 2 \mathrm{H}) ; 7.24(t, 2 \mathrm{H}) ; 7.46$ $(d, 2 \mathrm{H}) \mathrm{ppm}$ for 6 and at $7.83(d, 2 \mathrm{H}) ; 8.41(d, 2 \mathrm{H})$; $6.83(d, 2 \mathrm{H}) ; 7.28(t, 2 \mathrm{H}) ; 7.22(t, 2 \mathrm{H}) ; 8.03(d, 2 \mathrm{H})$; $7.69(d, 2 \mathrm{H}) ; 7.49(t, 2 \mathrm{H}) ; 7.07(t, 2 \mathrm{H}) ; 7.31(d, 2 \mathrm{H})$ ppm for $\mathbf{1 1}$ are assigned to be H2, H3, H4, H5, H8, 
Table 3. Tautomeric species of the 2-hydroxy Schiff bases in solution.

\begin{tabular}{|c|c|c|c|}
\hline Aldimine type & Compound & & Tautomer found by NMR spectroscopy \\
\hline \multirow[t]{2}{*}{ Salicylaldimine } & $(5-8)$ & $\begin{array}{l}\mathrm{CDCl}_{3} \\
\mathrm{DMSO}\end{array}$ & $\begin{array}{l}\text { Phenol-imine (one tautomer; A) } \\
\text { Phenol-imine (one tautomer; A) }\end{array}$ \\
\hline & (9) & $\begin{array}{l}\mathrm{CDCl}_{3} \\
\mathrm{DMSO}\end{array}$ & $\begin{array}{l}\text { Phenol-imine (two tautomers; A and B or C) } \\
\text { Phenol-imine (one tautomer; A) }\end{array}$ \\
\hline \multirow[t]{2}{*}{ Naphthaldimine } & $(10-12)$ & $\begin{array}{l}\mathrm{CDCl}_{3} \\
\mathrm{DMSO}\end{array}$ & $\begin{array}{l}\text { Keto-amine }(\mathrm{F}) \text {; phenol-imine }(\mathrm{A}) \\
\text { Keto-amine }(\mathrm{F})\end{array}$ \\
\hline & (13) & $\begin{array}{l}\mathrm{CDCl}_{3} \\
\mathrm{DMSO} \\
\mathrm{CDCl}_{3} / \mathrm{DMSO}\end{array}$ & $\begin{array}{l}\text { Phenol-imine (one tautomer; A) } \\
\text { Phenol-imine (one tautomer; A) } \\
\text { Phenol-imine (one tautomer; A) }\end{array}$ \\
\hline
\end{tabular}

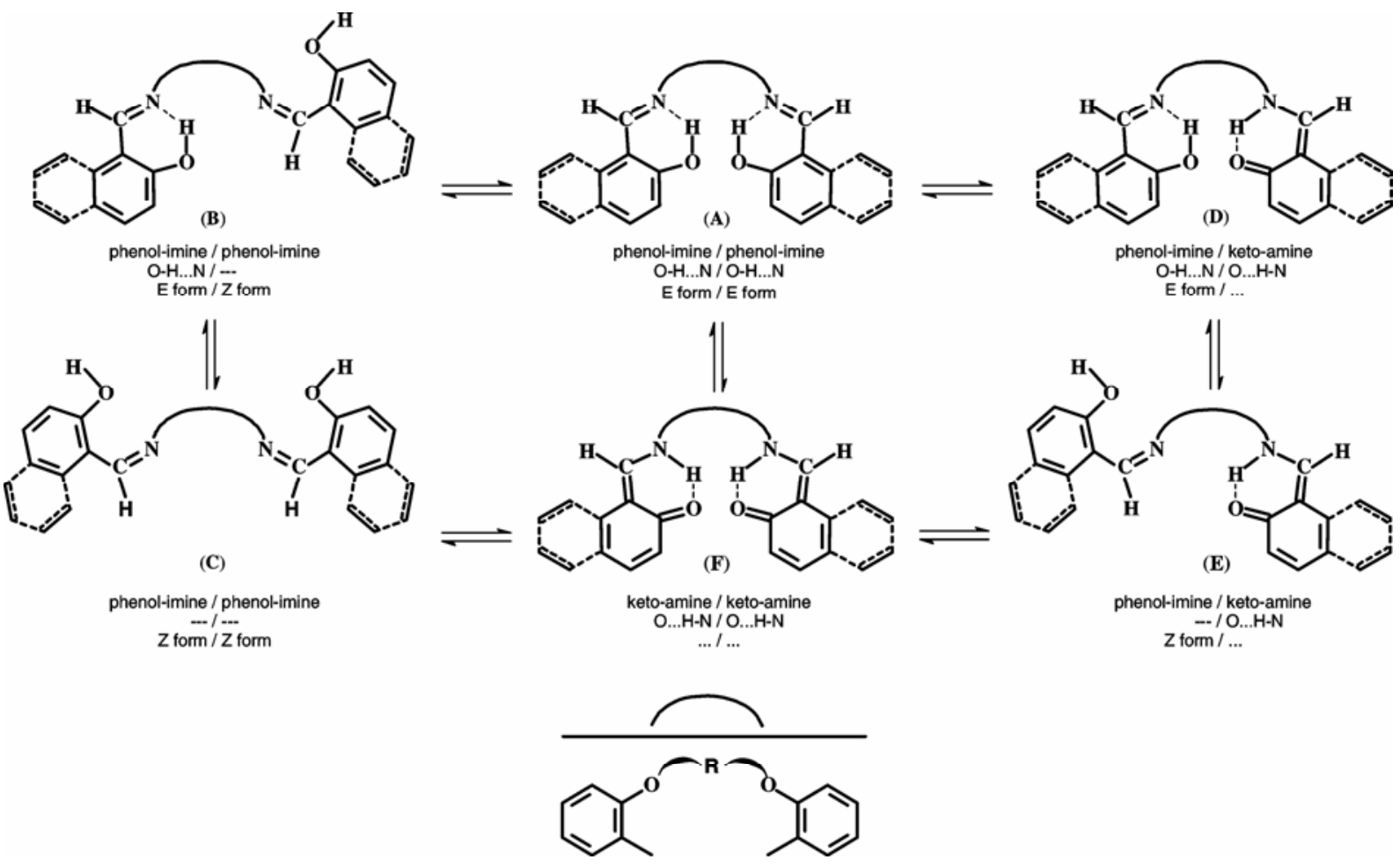

Scheme 2.

$\mathrm{H} 9, \mathrm{H} 10$ and $\mathrm{H} 11$ for 6 and $\mathrm{H} 2, \mathrm{H} 3, \mathrm{H} 8, \mathrm{H} 9, \mathrm{H} 10$, H1 1, H13, H14, H15, H16 for 11 (table S1). All of the possible carbon peaks are observed in the ${ }^{13} \mathrm{C}$ NMR spectra, as expected. Assignments of the aromatic protons and carbons have been made ambiguously by two-dimensional heteronuclearcorrelated experiments (HETCOR) using the values corresponding to ${ }^{1} J_{(\mathrm{C}, \mathrm{H})}$, heteronuclear multiple bond correlation $\left({ }^{1} \mathrm{H}-{ }^{13} \mathrm{C}\right.$ HMBC $)$ using the values corresponding to ${ }^{2} J_{(\mathrm{C}, \mathrm{H})}$ or ${ }^{3} J_{(\mathrm{C}, \mathrm{H})}$ between the carbons and protons and DEPT spectra. As examples, figure 2, S2 in Supplementary materials and 4 of 6 and figures S1 in Supplementary materials, 3 and 5 of $\mathbf{1 1}$ are given. In these figures, all of the aromatic proton and carbon signals are labeled. The other salicyclaldimine and naphthaldimine derivatives show similar characteristics as those discussed in compounds 6 and 11 in both DMSO and $\mathrm{CDCl}_{3}$ (tables $\mathrm{S} 1, \mathrm{~S} 2$ and S3). All of the aliphatic protons and carbons are easily distinguishable. In compounds 7,8 and 12 which contain $o$-xylylene precursor, the $\mathrm{Cl}^{\prime}$, $\mathrm{C} 2^{\prime}$ and $\mathrm{C}^{\prime}{ }^{\prime}$ carbons and $\mathrm{H} 2^{\prime}$ and $\mathrm{H}^{\prime}$ ' protons are also easily distinguished and assigned by using HETCOR. HMBC and DEPT methods (tables S1 and S2). ${ }^{1} \mathrm{H}-{ }^{13} \mathrm{C}$ HMBC multiple bond correlations, a modified version of HETCOR, were applied on 6 
Table 4. 2D ${ }^{1} \mathrm{H}-{ }^{13} \mathrm{C}$ HETCOR and HMBC correlations for $\mathbf{6}$ and $\mathbf{1 1}$.

\begin{tabular}{|c|c|c|c|c|c|c|}
\hline & \multirow[b]{2}{*}{ Atom } & \multirow{2}{*}{$\frac{\text { HETCOR }}{{ }^{1} J}$} & \multicolumn{4}{|c|}{$\mathrm{HMBC}[J(\mathrm{C}, \mathrm{H})]$} \\
\hline & & & ${ }^{2} J$ & ${ }^{3} J$ & ${ }^{4} J$ & ${ }^{\text {Spatial } J}$ \\
\hline \multirow[t]{10}{*}{6} & $\mathrm{H} 2$ & $\mathrm{C} 2$ & $\mathrm{C} 1, \mathrm{C} 3$ & - & - & - \\
\hline & $\mathrm{H} 3$ & $\mathrm{C} 3$ & $\mathrm{C} 2$ & $\mathrm{C} 1$ & - & - \\
\hline & $\mathrm{H} 4$ & $\mathrm{C} 4$ & $\mathrm{C} 5$ & - & - & - \\
\hline & H5 & $\mathrm{C} 5$ & $\mathrm{C} 4$ & - & - & - \\
\hline & H8 & $\mathrm{C} 8$ & $\mathrm{C} 7, \mathrm{C} 9$ & - & - & - \\
\hline & H9 & C9 & $\mathrm{C} 8$ & $\mathrm{C} 7$ & - & - \\
\hline & $\mathrm{H} 10$ & $\mathrm{C} 10$ & C11 & $\mathrm{C} 12$ & - & - \\
\hline & H11 & C11 & $\mathrm{C} 10, \mathrm{C} 12$ & - & - & - \\
\hline & $\mathrm{HC}=\mathrm{N}$ & $\mathrm{HC}=\mathrm{N}$ & C6 & $\mathrm{C} 1, \mathrm{C} 7$ & - & - \\
\hline & $\mathrm{OH}$ & - & $\mathrm{Cl}$ & $\mathrm{C} 6$ & $\mathrm{C} 5$ & - \\
\hline \multirow[t]{11}{*}{11} & $\mathrm{H} 2$ & $\mathrm{C} 2$ & $\mathrm{C} 1$ & $\mathrm{C} 4$ & - & \\
\hline & $\mathrm{H} 3$ & $\mathrm{C} 3$ & - & - & - & C7, C8 \\
\hline & H8 & C8 & $\mathrm{C} 7$ & $\mathrm{C} 10$ & - & - \\
\hline & H9 & C9 & $\mathrm{C} 10$ & - & - & - \\
\hline & $\mathrm{H} 10$ & $\mathrm{C} 10$ & C11 & $\mathrm{C} 12$ & - & - \\
\hline & H11 & C11 & $\mathrm{C} 10, \mathrm{C} 12$ & - & - & - \\
\hline & H13 & $\mathrm{C} 13$ & $\mathrm{C} 4, \mathrm{C} 14$ & - & - & - \\
\hline & H14 & C14 & C13 & $\mathrm{C} 4$ & - & - \\
\hline & H15 & $\mathrm{C} 15$ & C16 & $\mathrm{C} 5$ & - & - \\
\hline & H16 & C16 & $\mathrm{C} 5, \mathrm{C} 15$ & - & - & - \\
\hline & $\mathrm{HC}-\mathrm{N}$ & $\mathrm{HC}-\mathrm{N}$ & $\mathrm{C} 1, \mathrm{C} 5$ & $\mathrm{C} 7$ & - & $\mathrm{C} 15$ \\
\hline
\end{tabular}

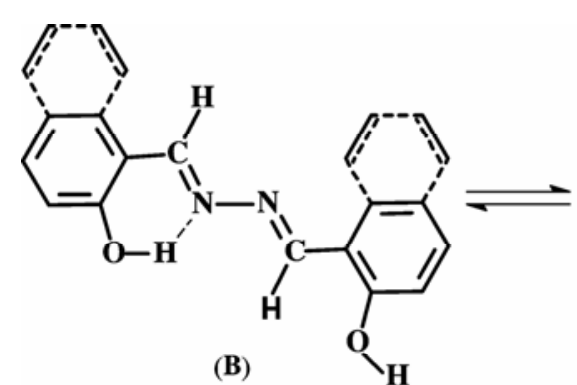

phenol-imine / phenol-imine

$$
\mathrm{O}-\mathrm{H} \text {...N / -.- }
$$

E form / E form

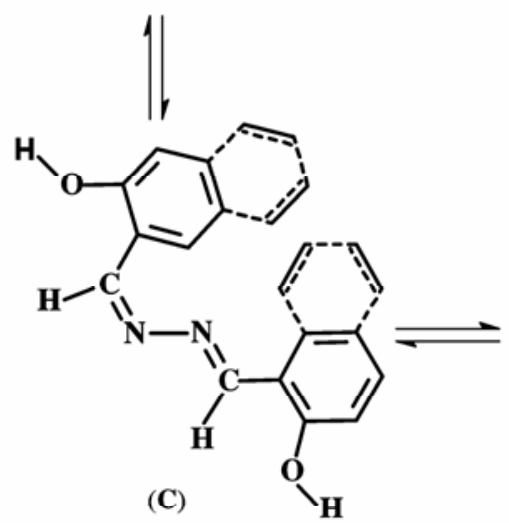

phenol-imine / phenol-imine

$$
\text { form / } \mathrm{E} \text { form }
$$

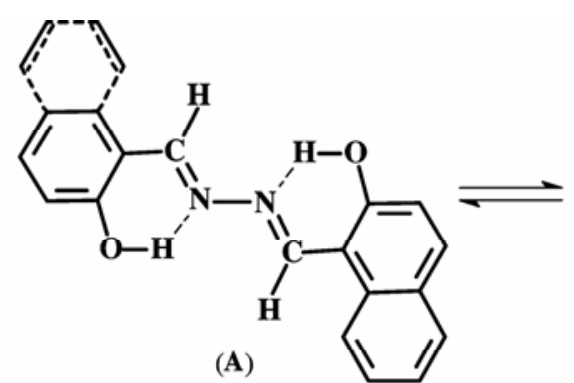

phenol-imine / phenol-imine

O-H...N / O-H...N

$E$ form / $E$ form
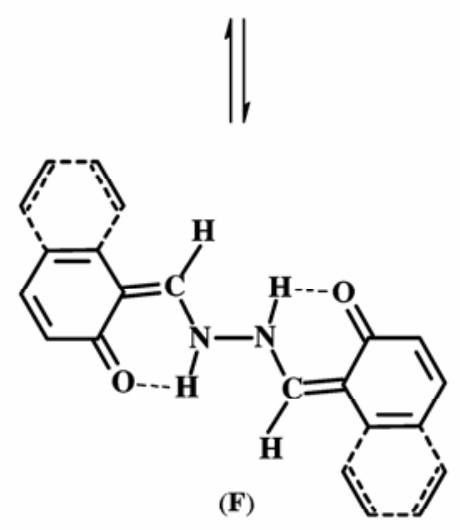

keto-amine / keto-amine

O... H-N / O...H-N

... $/ \ldots$

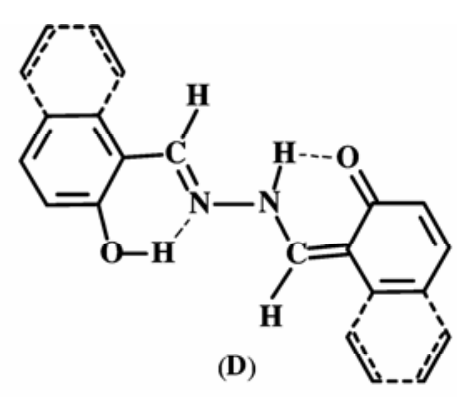

phenol-imine / keto-amine

$$
\mathrm{O}-\mathrm{H} \text {...N / O...H-N }
$$

E form / ...

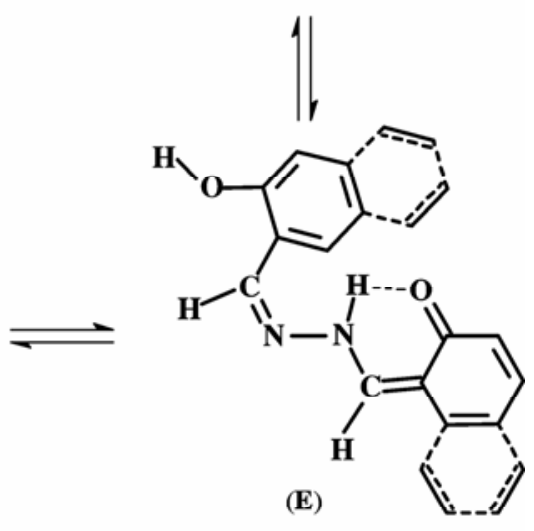

phenol-imine / keto-amine

-.- / O...H-N

Scheme 3. 

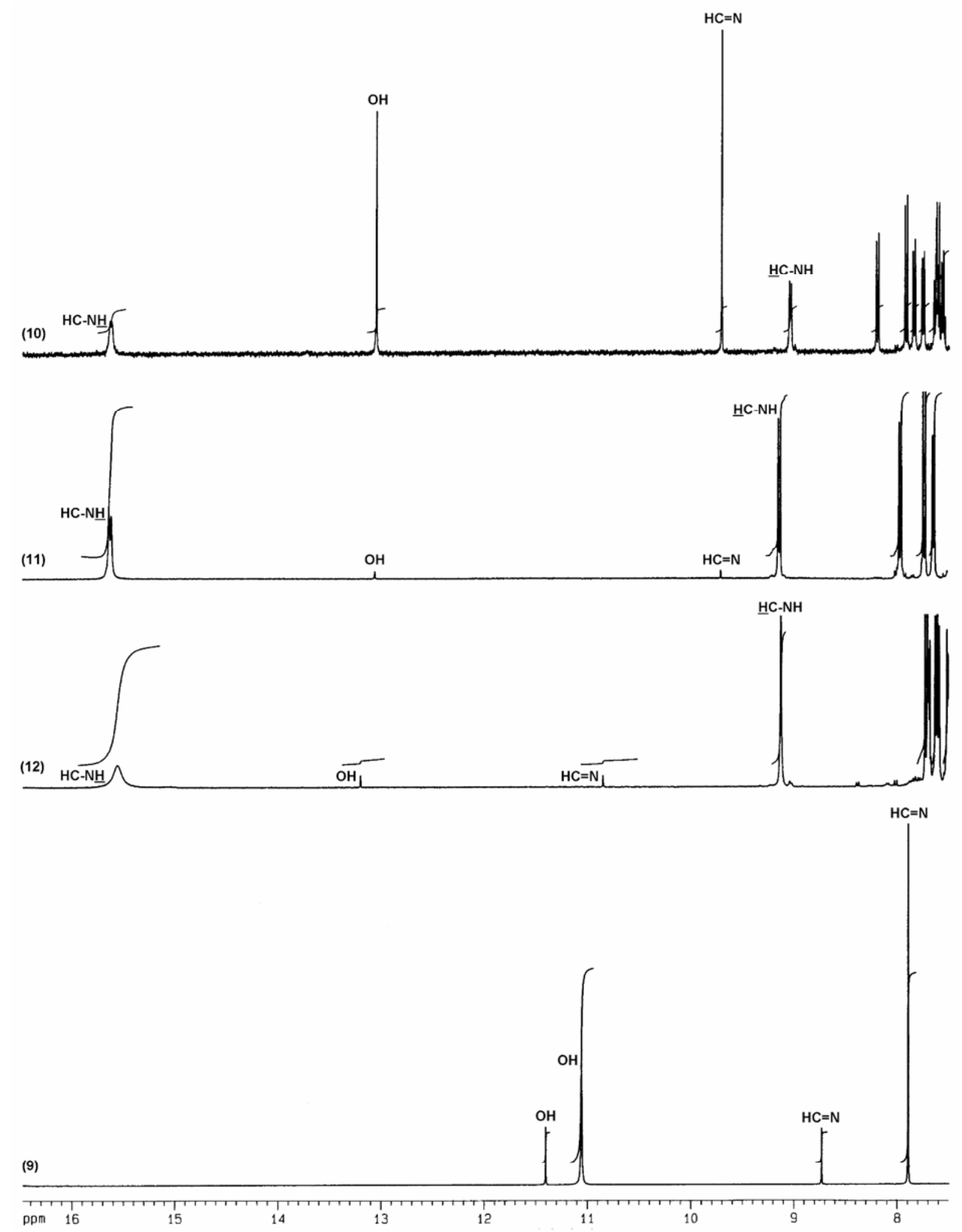

Figure 1. ${ }^{1} \mathrm{H}$ NMR spectra of naphthaldimine (10-12) and salicylaldimine (9) derivatives in $\mathrm{CDCl}_{3}$.

and 11 in order to determine the long range ${ }^{1} \mathrm{H}-{ }^{13} \mathrm{C}$ connectivities (figures S2 and 3, table 4). The $\underline{\mathrm{HCN}}$ protons of 6 and 11 were located near to $\mathrm{C} 7$ rather than hydroxyl proton $(\mathrm{O}-\mathrm{H}$...N) or amine proton $(\mathrm{O} \ldots \mathrm{H}-\mathrm{N})$ owing to the relationship observed; $\underline{\mathrm{HCN}}$ protons are correlated with $\mathrm{C} 1, \mathrm{C} 6$ and $\mathrm{C} 7$ atoms for 


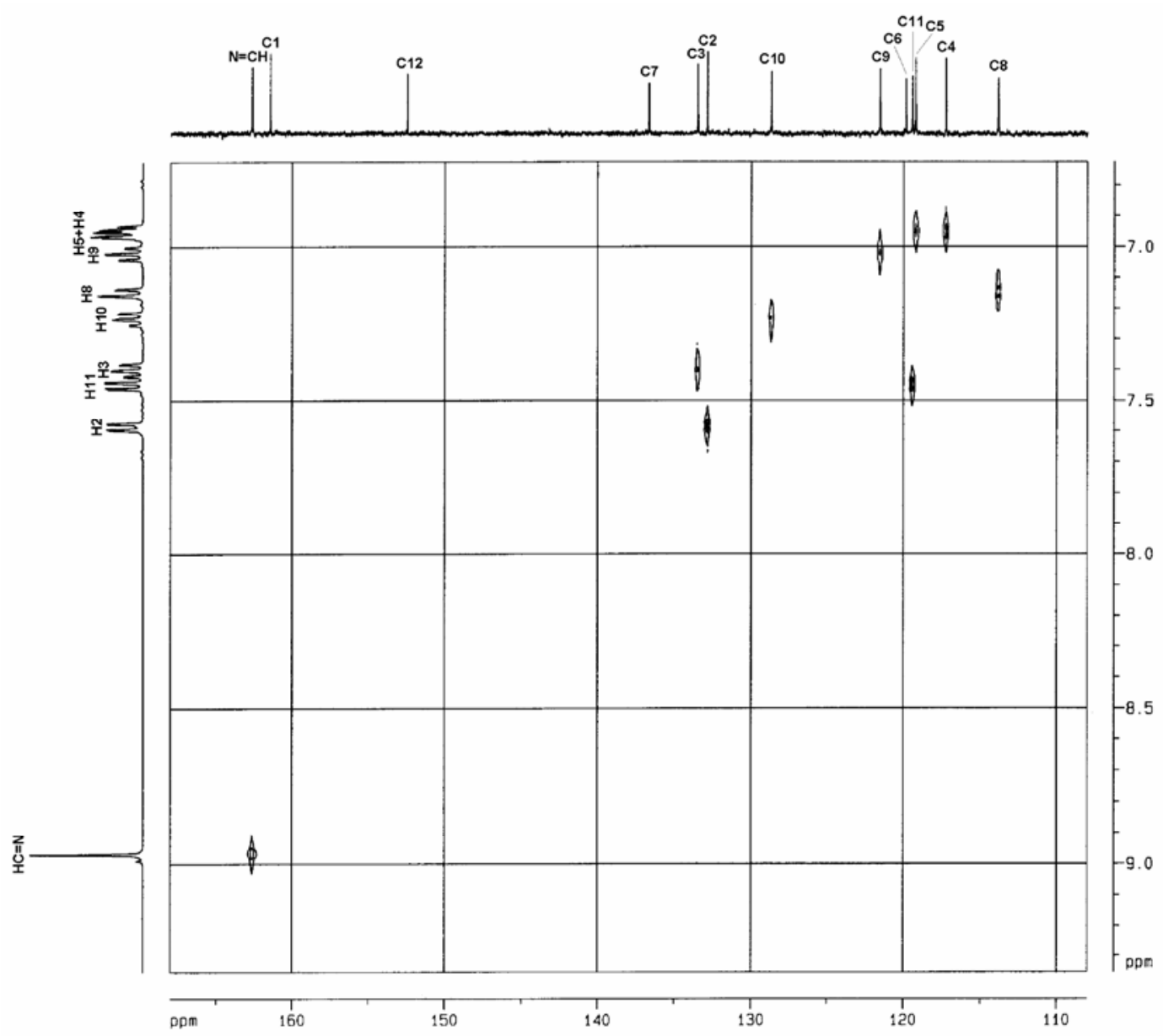

Figure 2. HETCOR spectrum of $\mathbf{6}$.

6 and $\mathrm{C} 1, \mathrm{C} 5, \mathrm{C} 7$ and $\mathrm{C} 15$ atoms for 11. Consequently, according to the NMR results (HETCOR and $\mathrm{HMBC}$ ), the possible conformations of $\mathbf{6}$ and $\mathbf{1 1}$ in DMSO solution are illustrated in figure 6.

\subsection{UV-visible spectroscopy}

In the UV-visible spectra of salicylaldimine and naphthaldimine derivatives, four main bands are to be expected; namely the first $(210-234 \mathrm{~nm})$ and second (240-282 nm) bands are atributed to the $\pi \rightarrow \pi^{*}$ transitions of aromatic rings. The third band at $300-340 \mathrm{~nm}$ is assigned to the $\pi \rightarrow \pi^{*}$ transitions of $\mathrm{C}=\mathrm{N}$ group. The forth band at $>400 \mathrm{~nm}$ involves $n \rightarrow \pi^{*}$ transitions of $\mathrm{C}=\mathrm{O}$ group. The $\mathrm{UV}$-vis spectra of the compounds (5-13) were studied in polar and non-polar solvents both in acidic $\left(\mathrm{CF}_{3} \mathrm{COOH}\right)$ and basic $\left(\mathrm{NEt}_{3}\right)$ media. The keto-amine isomer ratios of the compounds in various solvents, acidic and basic media are listed in table S4 in Supplementary materials. The UV spectra of (6 and 11) and (9 and 13) in different solvents are illustrated in figures S3 and S4 in Supplementary materials, respectively as examples, indicating the phenol-imine/keto-amine tautomeric forms. In addition, figure S5 in Supplementary materials shows the acidic and basic effects of 8 in $\mathrm{CH}_{2} \mathrm{Cl}_{2}$ solution, which is also an example for salicylaldimines. Generally, the keto-amine tautomer was always observed when the Schiff bases were derived from 2-hydroxynaphthaldehyde. ${ }^{37,51}$ For Schiff bases derived from salicylaldehyde, the ketoamine form was not observed in polar and non-polar solvents. No absorption bands were observed above $400 \mathrm{~nm}$ in DMSO, EtOH, $\mathrm{CH}_{2} \mathrm{Cl}_{2}$ and $n$-hexane for compounds (5-9). However, for the compounds (10-13) new additional bands were detected at $>400 \mathrm{~nm}$, in the same solvents. The keto-amine/ phenol-imine tautomeric equilibria (calculated in table S4) are present for the compounds. In naphthaldimine compounds (10-12), the keto-amine form was dominant in solvent, acidic and basic media. But, for compound 13, in solid-state ${ }^{38}$ and in $\mathrm{CDCl}_{3}$ 


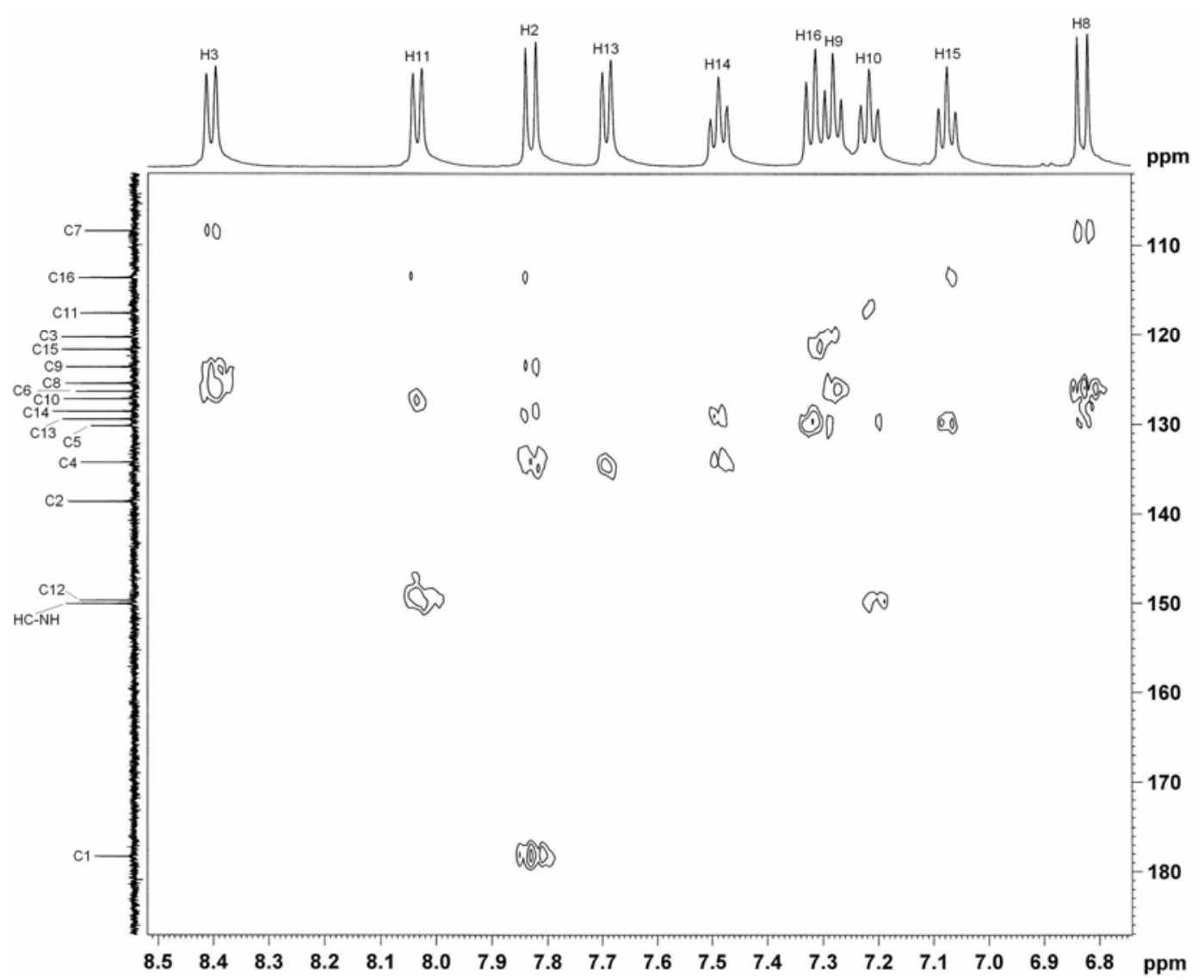

Figure 3. HMBC correlations for 11.

solution (table S3), there is only phenol-imine tautomer, whereas in DMSO, EtOH, $\mathrm{CH}_{2} \mathrm{Cl}_{2}$ and $n$-hexane, keto-amine tautomer is dominant. In addition, in Schiff bases derived from the salicylaldehyde (5-9), only the phenol-imine form was observed in pure solvents and basic media, while the keto-amine tautomer was dominant only in acidic solution of $\mathrm{CH}_{2} \mathrm{Cl}_{2}$ and $n$-hexane, except 9 . These results in acidic solution indicate that salicylaldimines (5-8) give salts with $\mathrm{CF}_{3} \mathrm{COOH}$, but 9 does not seem to afford any salt with $\mathrm{CF}_{3} \mathrm{COOH}$. For the compounds (5-9), the absence of keto-amine form in acidic solutions of DMSO and EtOH may probably be explained by the hydrogen bonding to $\mathrm{CF}_{3} \mathrm{COOH}$. In basic solution, the keto-amine $(\mathrm{O} \ldots \mathrm{H}-\mathrm{N})$ and phenol-imine $(\mathrm{O}-\mathrm{H} \ldots \mathrm{N})$ ratios were approximately the same as in the respective pure solvent media of all the compounds. In acidic solution, for the naphthaldimine derivatives of the compounds (10-12) the keto-amine tautomer ratio $(\%)$ was increased to 61-70 with respect to pure solvents. The bathochromic shifts both above and below $400 \mathrm{~nm}$ in all of the solvents studied (DMSO, EtOH, $\mathrm{CH}_{2} \mathrm{Cl}_{2}$ and $n$-hexane) do not depend on the solvent polarities for all the compounds.

\section{$3.4 X$-Ray analysis of $\mathbf{8}$}

Single crystal X-ray structure of compound $\mathbf{8}$ is reported to further corroborate the structural assignments. The molecular structure with atom-numbering scheme is shown in figure 7 . The bond lengths and angles with some selected torsion angles are given in table 2. Compound $\mathbf{8}$ is in the phenol-imine form in solution, at least in $\mathrm{CDCl}_{3}$ according to the $\mathrm{NMR}$ result (table $\mathrm{S} 1$ ), in $\mathrm{DMSO}, \mathrm{EtOH}, \mathrm{CH}_{2} \mathrm{Cl}_{2}$ and $n$-hexane (table $\mathrm{S} 4)$. The two strong intramolecular O-H...N hydrogen bondings [Ol-H1A 0.96(3), H1A...N1 1.72(3), Ol...N1 2.596(2) A, Ol-H1A...N1 $150(2)^{\circ}$ and $\mathrm{O} 4-\mathrm{H} 4 \mathrm{~A} \quad 0 \cdot 88(3), \mathrm{H} 4 \mathrm{~A} \ldots \mathrm{N} 2 \quad 1 \cdot 81(2)$, O4...N2 2.599(2) $\AA, \quad$ O4-H4A...N2 $\left.148(2)^{\circ}\right]$ also show that compound 8 is in phenol-imine form (figure 7, table S5 in supplementary materials) in the solid state. On the basis of crystal studies of intramolecular hydrogen bonds, a short hydrogen bond 
(a)
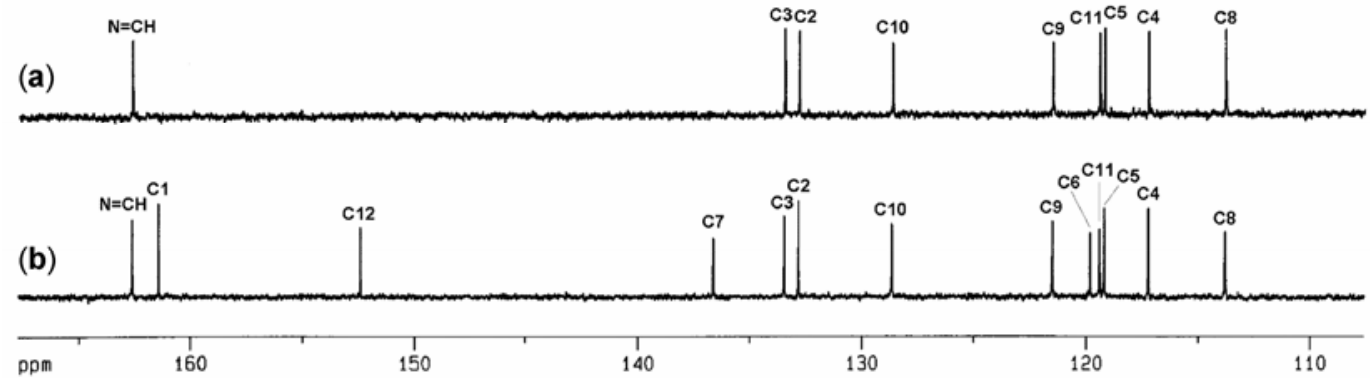

Figure 4. (a) DEPT and (b) ${ }^{13} \mathrm{C}$ NMR spectrum of 6.

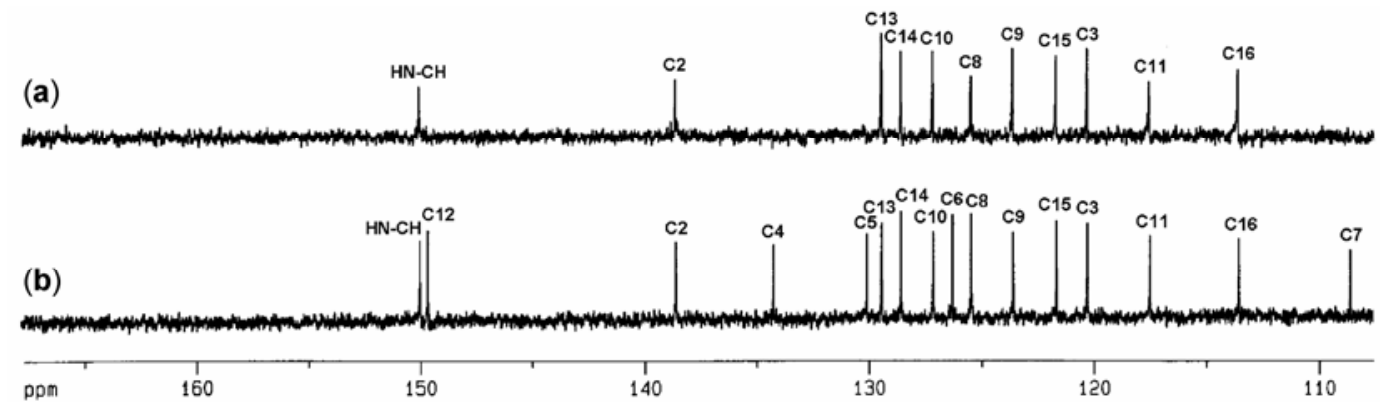

Figure 5. (a) DEPT and (b) ${ }^{13} \mathrm{C}$ NMR spectrum of 11.
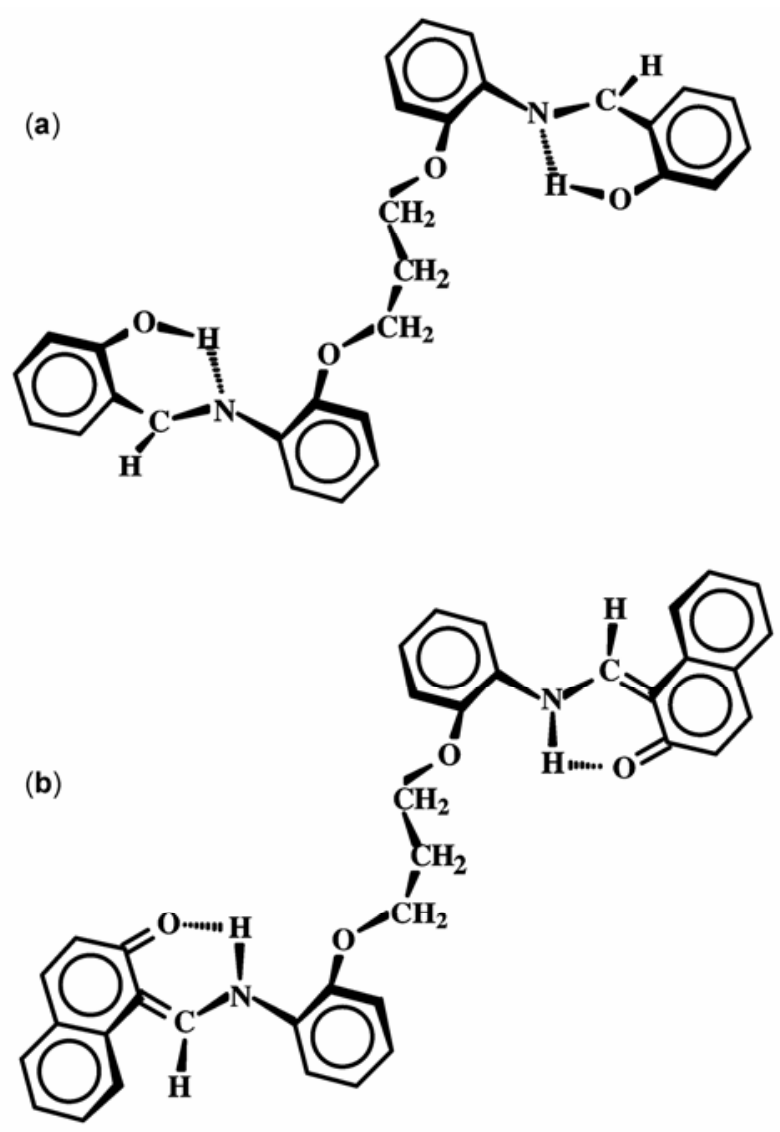

Figure 6. The possible conformers of (a) compound 6 and (b) compound $\mathbf{1 1}$ at ambient temperature in DMSO. associated with a charge flow through the system of conjugated double bonds is denoted 'resonanceassisted hydrogen bonding ${ }^{44,52}$ and a delocalization parameter, $Q=\left(d_{1}-d_{4}\right)+\left(d_{3}-d_{2}\right)$, is defined (distances $d_{1}$ to $d_{4}$ are as defined in table S5). In general, the $Q$ values have positive and negative signs in phenol-imine and keto-amine tautomers, respectively, except for XIV and XV (table S5). Compounds XIV and XV have $\mathrm{OH}$ groups located on the salicylidene moieties, and in the asymmetric units where there are two independent molecules. The molecules are linked by strong intra- and intermolecular $\mathrm{O}-\mathrm{H}$...O hydrogen bonds into a three dimensional network. ${ }^{64,65}$ Hence, the $\mathrm{O}-\mathrm{H} \ldots \mathrm{O}$ hydrogen bonds may change the charge flow through the system of conjugated double bonds and $Q$ values of XIV and XV. In compound $8, Q$ values are calculated as $0 \cdot 116(3)$ and $0 \cdot 122(2) \AA$ indicating also that the compound is in the phenol-imine form. These values are comparable with the corresponding values in the analogous compounds (table S5). There is no clear relationship between the corresponding $\mathrm{Q}$ and $\mathrm{N}$...O values.

In 8, the $\mathrm{C} 2=\mathrm{C} 3 \quad[1 \cdot 376(4) \AA]$ and $\mathrm{C} 31=\mathrm{C} 32$ $\left[\begin{array}{ll}1.364(3) & \AA\end{array}\right]$ bonds are shorter than the expected value $[\sim 1.40 \AA]$. The $\mathrm{Cl}=\mathrm{O} 1 \quad[1.345(3) \AA]$ and $\mathrm{C} 30=\mathrm{O} 4[1.350(2) \AA]$ bonds are longer, while $\mathrm{N} 1=\mathrm{C} 7 \quad[1 \cdot 278(2) \AA]$ and $\mathrm{N} 2=\mathrm{C} 28 \quad[1 \cdot 272(2) \AA]$ 
bonds are shorter than those of naphthaldimine derivatives, which can be explained by the quinoidal structure. $^{73}$ These values also support that the compound is in phenol-imine form in the solid state. The $\Phi_{\mathrm{CN}}$ torsion angles $\mathrm{C} 8-\mathrm{N} 1-\mathrm{C} 7-\mathrm{C} 6\left[-175.45(15)^{\circ}\right]$ and $\mathrm{C} 25-\mathrm{N} 2-\mathrm{C} 28-\mathrm{C} 29\left[-179 \cdot 12(16)^{\circ}\right]$ show that the configurations about the $\mathrm{N} 1=\mathrm{C} 7$ and $\mathrm{N} 2=\mathrm{C} 28$ bonds are anti $(1 E)$, which are in accordance with the phenol-imine $(E$ form)/phenol-imine ( $E$ form) [scheme $1,(\mathrm{~A})]$.

\section{Conclusions}

On the basis of the imine backbone, a straightforward method was used to prepare the 2-hydroxy salicylaldimines and naphthaldimines, which are likely to be intramolecular hydrogen bonding agents, e.g. O-H...N (phenol-imine tautomer) and $\mathrm{O} \ldots \mathrm{H}-\mathrm{N}$ (keto-amine tautomer). In this study, the salicylaldimine and naphthaldimine derivatives have been systematically characterized in detail by using IR, MS, UV-vis, 1D (DEPT, ${ }^{1} \mathrm{H}$ and ${ }^{13} \mathrm{C}$ ) and 2D (HETCOR and HMBC) NMR techniques. 2Dtechniques are very useful for assignments of the all aromatic protons and carbons. The structure of the representative compound $\mathbf{8}$, which is a salicyaldimine derivative, has been unequivocally confirmed from single crystal X-ray diffraction analysis to establish the intramolecular hydrogen bonds and phenolimine tautomer. The tautomeric equilibria of the compounds have also been investigated in polar and non-polar solvents by using NMR and UV-vis spectral data. In addition, for 2-hydroxy Schiff bases in table S5, delocalization parameters ' $Q$ ' have been

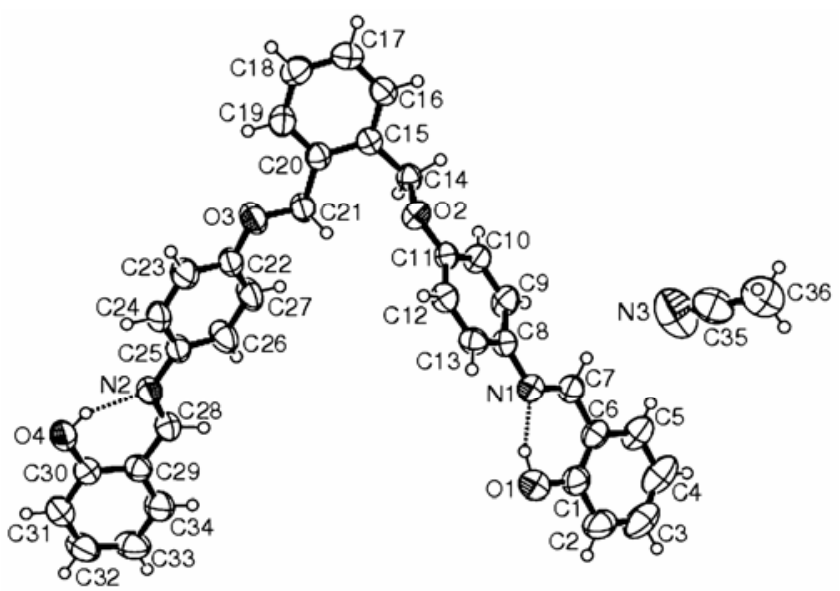

Figure 7. Molecular structure of 8. Thermal ellipsoids are drawn at the $40 \%$ probability level. Hydrogen bonds are shown as dashed lines. calculated in order to discuss the tautomerism in the solid state. As known, tautomerism is a very complex phenomenon and more detailed investigations on these types of compounds are needed.

\section{Supplementary materials}

The X-ray crystallographic data in the CIF format for the structure reported in this paper have been deposited with the Cambridge Crystallographic Data Center, and the supplementary crystallographic data can be obtained free of charge on request at www.ccdc.cam.ac.uk/conts/retrieving.html (or from The Director, Cambridge Crystallographic Data Center, CCDC, 12 Union Road, Cambridge CB2 1EZ, UK; fax: +44(0)1223-336033; e-mail: deposit@ ccdc.cam.ac.uk), quoting the CCDC number 653274. NMR characterization (tables S1, S2 and S3 and figures $\mathrm{S} 1$ and $\mathrm{S} 2$ ), UV-vis data (table S4 and figures S3, S4 and S5) and table S5 are available free of charge on the Internet.

\section{Acknowledgements}

The authors wish to acknowledge Ankara University Research Fund (grant No. 20020705070) and Hacettepe University Scientific Research Unit (grant No. 0202602002 ) for financial support. The authors are grateful to the organizers of the 2005 ACA Summer Course in Small Molecule Crystallography at The Indiana University of Pennsylvania for the crystallographic data collection.

\section{References}

1. Stewart J and Lingafelter E C 1959 Acta Cryst. 12842

2. Calligaris M, Nardin G and Randaccio L 1972 Coord. Chem. Rev. 7385

3. Maslen H S and Waters T N 1975 Coord. Chem. Rev. 17137

4. Bhatia S C, Bindlish J M, Saini A R and Jain P C 1981 J. Chem. Soc., Dalton Trans. 1773

5. Kessisoglu D P, Raptopoulou C P, Bakalbassis E G, Terzis A and Mrozinski J 1992 Inorg. Chem. 314339

6. Hökelek T, Gündüz N, Hayvalı Z and Kılıç Z 1995 Acta Cryst. C51 880

7. Hökelek T, Gündüz N, Hayvalı Z and Kılıç Z 1995 J. Chem. Crystallogr. 25827

8. Metzler C M, Cahill A and Metzler D E $1980 \mathrm{~J}$. Am. Chem. Soc. 1026075

9. Lenarcik B, Wisniewski $M$ and Gabryszewski $M$ 1980 Pol. J. Chem. 541869

10. El-Naggar A M, Ahmed F S M and Badie M F 1981 J. Heterocycl. Chem. 1891 
11. Pyrz J W, Roe A L, Stern L J and Que Jr L 1985 J. Am. Chem. Soc. 107614

12. Chen D and Martel A E 1987 Inorg. Chem. 261026

13. Lodzinska A, Golinska F and Rozploch F 1989 Pol. J. Chem. 63355

14. Hayvalı Z, Hayvalı M, Kılıç Z, Hökelek T and Weber E 2003 J. Incl. Phenom. Macrocycl. Chem. 45285

15. Hayvalı M and Hayvalı Z 2004 Synt. React. in Inorg. Met-Org. Chem. 34713

16. Hayvalı Z, Gündüz N, Kılıç Z and Weber E $1999 \mathrm{~J}$. Pract. Chem. 341568

17. Yıldız M, Kılıç Z and Hökelek T 1998 J. Mol. Struct. 4411

18. Salman S R, Farrant R D and Lindon J C 1991 Spectrosc. Lett. 241071

19. Pizzala H, Carles M, Stone M E E and Thevand A 2000 J. Chem. Soc., Perkin Trans. 2935

20. Dal H, Süzen Y and Şahin E 2007 Spectrochim. Acta A67 807

21. Yeap G-Y, Ha S-T, Ishizawa N, Suda K, Boey P-L and Mahmood V A K 2003 J. Mol. Struct. 65887

22. Fermandez-G J M, Del Rio-Portilla F, Quiroz-Garcia B, Toscano R A and Salcedo R 2001 J. Mol. Struct. 561197

23. Gilli P, Bertolasi V, Ferretti V and Gilli G $2000 \mathrm{~J}$. Am. Chem. Soc. 12210205

24. Kaitner B and Pavlovic G 1996 Acta Cryst. C52 2573

25. Barbara P F, Rentzepis P M and Brus L E $1980 \mathrm{~J}$. Am. Chem. Soc. 1022786

26. Hadjoudis E $1981 \mathrm{~J}$. Photochem. 17355

27. Higelin D and Sixl H 1983 Chem. Phys. 77391

28. Dürr H and Bouas-Laurent H 1990 Photochromism: molecular and systems (Amsterdam: Elsevier)

29. Cohen M D, Schmidt G M J and Flavian S $1964 J$. Chem. Soc. 2041

30. Hadjoudis E 1995 Mol. Eng. 5301

31. Chantarasiri N, Tuntulani T, Tongroung P, Seangprasertkit-Magee R and Wannatong W 2000 Eur. Poly. J. 36695

32. Zhao J, Zhao B, Liu J, Xu W and Wang Z 2001 Spectrochim. Acta A57 149

33. Costamagna J, Vargas J, Latorre R, Alvarado A and Mena G 1992 Coord. Chem. Rev. 11967

34. Salman S R, Shawkat S H and Al-Obaidi G M 1990 Can. J. Spect. 3525

35. Salman S R, Lindon J C, Farrant R D and Carpenter T A 1993 Magn. Res. Chem. 31991

36. Gavranic M, Kaitner B and Mestrovic E $1996 \mathrm{~J}$. Chem. Crystallogr. 2623

37. Elerman Y, Kabak M, Elmalı A and Svoboda I 1998 Acta Cryst. C54 128

38. Hökelek T, Bilge S and Kılıç Z 2006 Anal. Sci. 22115

39. Hökelek T, Kılıç Z, Işıklan M and Hayvalı M 2002 Anal. Sci. 18215

40. Zhu L-N, Li C-Q and Li X-Z 2006 Acta Cryst. E62 4643

41. Hökelek T, Kılıç Z, Işıklan M, Dal H and Nazır H 2002 Anal. Sci. 181281

42. Bruker Program 1D WIN-NMR (release 6.0) and 2D WIN-NMR (release 6.1)
43. Özgüç B, Bilge S, Çaylak N, Demiriz Ş, İşler H, Hayvalı M, Kılıç Z and Hökelek T 2005 J. Mol. Struct. 74839

44. Hökelek T, Bilge S, Demiriz Ş, Özgüç B and Kılıç Z 2004 Acta Cryst. C60 803

45. Temel H, Çakır Ü, Uğraș H İ, and Șekerci M $2003 \mathrm{~J}$. Coord. Chem. 56943

46. Xu X-X, You X-Z and Sun Z-F 1994 Acta Cryst. C50 1169

47. Temel H 2004 J. Coord. Chem. 57723

48. Athappan P R and Rajagopal G 1996 Polyhedron 15527

49. Sheldrick G M 1997 SHELXS97 and SHELXL97 University of Göttingen Germany

50. Freedman H H 1961 J. Am. Chem. Soc. 832900

51. Hökelek T, Işıklan M and Kılıç Z 2000 Anal. Sci. 16 99

52. Steiner T 2002 Angew. Chem. Int. Ed. 4148

53. Sony S M M, Charles A, Ponnuswamya M N and Yathirajanb H S 2004 Acta Cryst. E60 1078

54. Thamotharan S, Parthasarathi V, Anitha S M, Prasad A, Raob T R and Lindenc A 2003 Acta Cryst. $\mathbf{E 5 9}$ 1856

55. Kartal A, Albayrak Ç, İskeleli N O, Ăgar E and Erdönmez A 2007 Acta Cryst. E63 1878

56. Gül Z S, Erşahin F, A ğar E and Ișık Ş 2007 Acta Cryst. E63 2902

57. Yüce S, Özek A, Albayrak Ç, Odabașığlu M and Büyükgüngör O 2004 Acta Cryst. E60 718

58. Karadayı N, Gözüyeșil S, Güzel B and Büyükgüngör O 2003 Acta Cryst. E59 161

59. Ünver H, Yıldız M, Kiraz A, İskeleli N O, Erdönmez A, Başaran D and Durlu T N 2006 J. Chem. Cryst. 36229

60. Yildız M, Ünver H, Erdeneri D, Ocak N, Erdönmez A and Durlu N 2006 Cryst. Res. Technol. 41600

61. Elmalı A, Elerman Y, Svoboda I and Fuess H 1998 Acta Cryst. C54 974

62. Gudasi K B, Patil M S, Vadavi R S, Shenoy R V and Patil S A 2006 Trans. Met. Chem. 31580

63. Ersanlı C, Albayrak Ç, Odabașıoğlu M and Ahmet E 2003 Acta Cryst. C59 601

64. Koşar B, Büyükgüngör $\mathrm{O}$, Albayrak Ç and Odabaşoğlu M 2004 Acta Cryst. C60 458

65. Koşar B, Albayrak Ç, Odabaşoğlu M and Büyükgüngör O 2005 Acta Cryst. E61 1097

66. Özek A, Yüce S, Albayrak Ç, Odabașığlu M and Büyükgüngör O 2005 Acta Cryst. E61 3179

67. Özek A, Yüce S, Albayrak Ç, Odabaşığlu M and Büyükgüngör O 2004 Acta Cryst. E60 826

68. Yüce S, Özek A, Albayrak Ç, Odabașığlu M and Büyükgüngör O 2004 Acta Cryst. E60 1217

69. Rao P V, Rao C P, Wegelius E K and Rissanen K 2003 J. Chem. Cryst. 33139

70. Özek A, Yüce S, Albayrak Ç, Odabaşığlu M and Büyükgüngör O 2004 Acta Cryst. E60 356

71. Sun X-X, Ma S-L, Huang H-B and Qi C-M 2007 Acta Cryst. $\mathbf{C 6 3} 87$

72. Popovic Z, Roje Z, Pavlovic G, Matkovic-Calogovic D and Giester G 2001 J. Mol. Struct. 59739

73. Hökelek T, Kılıç Z, Ișıklan M and Toy M $2000 \mathrm{~J}$. Mol. Struct. $\mathbf{5 2 3} 61$ 